\title{
Women's Body Exposure in Leisure Wear during the 1930s -Focused on Bathing Suits, Shorts, and Halters-
}

\author{
Yhe-Young Lee ${ }^{\dagger} \cdot$ Jane Farrell-Beck* \\ Dept. of Home Economics Education, Korea University \\ *Dept. of Apparel, Educational Studies \& Hospitality Management, Iowa State University \\ Received December 19, 2011; Revised June 7, 2012; Accepted June 25, 2012
}

\begin{abstract}
Social reactions to body exposure in American leisure wear (bathing suits, shorts, and halters) in the 1930s were analyzed to provide an understanding of the process of adopting more abbreviated and less-occasion specific styles of garments in women's fashion. The research questions were as follow: How did women expose their bodies in leisure wear during the 1930s? How did the social reaction to women's body exposure in leisure wear change throughout the 1930s? How did the body exposure in women's leisure wear play a significant role in the history of women's fashion? Primary sources were collected from issues of The New York Times published in the 1930s. Topics including dress, fashion, ethics, social ethics, and sexual ethics, were reviewed in The New York Times indices. The findings were analyzed and interpreted with reference to secondary sources that included books and research papers. The results showed that the body exposure of the styles as well as the place where these styles were worn was a public issue. Women were criticized and regulated for body exposure as well as for wearing bathing suits, shorts, and halters on the streets. However, the social regulations that restricted bathing suit styles almost disappeared by the end of the decade. This represented the change of social expectations toward body exposure in the 1930s. In addition, reports of laws that forbade the wearing of bathing suits, halters, and shorts outside of beaches, pools, and parks indicated women's increased attempts to expose their bodies in public places. However, reactions to women's body exposure in leisure wear changed to accept more flexibility in the social customs throughout the decade. These phenomena were a partial step toward the popularization of less occasion-specific styles - sportswear - that took place in the 20th century.
\end{abstract}

Key words: Body exposure, Leisure wear, Bathing suits, Halters, Shorts

\section{Introduction}

Women went back to longer skirts with the return of breasts, waists and hips in the late 1920s in western fashion. Some reminisced about the social meaning of short skirts of the 1920s, and were concerned about the long skirt's influence on women. One regarded the short skirt as a means for women to become close companions of men, since the short skirt offered women physical freedom to do things such as

\footnotetext{
${ }^{\dagger}$ Corresponding author

E-mail: young509@korea.ac.kr
}

flying, car racing, and dancing with men (Bolitho, 1930). Another person thought of short skirts as "a triumphant gesture of freedom on the part of women" (Flügel, 1931, p. 435). Some others regarded the longer skirt in the 1930s as an impediment to women participating in business (Burgess, 1932). There were people who were worried about the popularity of lengthened skirts of the late 1920 s, since special meanings of women's liberal lifestyles were assigned to the 1920s short skirts. However, women's daytime dresses did not reach down to the floor during the 1930s. Women's skirts remained above the ankle dur- 
ing the day. Longer dresses were popular only as eveningwear.

While dresses became longer, more body exposing leisure wear including shorts, halters and abbreviated bathing suits were popular during the 1930s. In this research, I focused on these leisure wear to provide better understanding about the process of adopting more body exposing styles of garments in women's fashion. The significance of body exposure in women's leisure wear will be discussed within the historical context in the conclusion. Specific research questions were as follows: How did women expose their bodies in leisure wear during the 1930s? How did the social reaction to women's body exposure in leisure wear change throughout the 1930s? How did the body exposure in women's leisure wear play a significant role in the history of women's fashion?

The term leisure wear is used in this paper to designate garments which are worn for leisure activities. Leisure wear used to mean sportswear during the 1930s. According to the dictionary of fashion, garments such as sweaters, skirts, blouses, pants and shorts that were worn for leisure time and spectator sports were called sportswear by the 1920and 1930s. However, the definition of sportswear changed to mean casual wear worn all around the day, as lifestyles became informal after World War II. The expansion of less formal life and fashion styles were the influence of Americans. Nowadays the concept of sportswear was widened to include mix-and-match possible separate garment items such as jackets, shirts, and pants along with more casual looking garments originally worn for sports (Calasibetta \& Tortora, 2003; Picken, 1999). Therefore, the term leisure wear means the sportswear of the 1930s in this paper.

Since there was a huge influence of Americans on popularization of leisure wear or sportswear, the scope of the research was confined to the 1930s American women's fashion. Primary sources for the research were found from an American daily newspaper, The New York Times, which was renowned for the accurate and unbiased reports (Commager, 1950; Stolberg, 1926). In order to look for the articles related to body exposure in women's leisure wear, related broader topics including dress, fashion, ethics, social ethics, and sexual ethics were found from The New York Times indices of the 1930s. I reviewed all the articles listed under these topics to gather specific information about the body exposure in leisure wear, since the term, body exposure, was not listed in the indices as one of the topics. Information such as sales numbers, social criticism, and regulations on leisure wear could be found. Since the articles on the body exposure of leisure wear were concentrated on bathing suits, shorts and halters, I decided to focus on these leisure wear in this paper. The contents of articles were understood within the social context of the time referring to the secondary sources including books and academic papers.

\section{Social Background}

One of the reasons for the public attention to the leisure wear could be found in the social context of the time in America. With the increase of unemployment during the Great Depression, the U.S. government provided indirect relief by creating employment. Under the New Deal, the federal government spent about $\$ 1.5$ billion on constructing or improving facilities such as camps, picnic grounds, trails, swimming pools and parks between 1932 and 1937 through agencies such as the Civilian Conservation Corps and the Works Progress Administration. The Works Progress Administration made or repaired 12,700 playgrounds, 8,500 gymnasiums or recreation buildings, 750 swimming pools, 1,000 ice skating rinks, and 64 ski jumps. The National Youth Administration and the Recreation Division of the Works Progress Administration trained and employed people in recreation services including parks, playgrounds, athletic fields, beaches, and swimming pools. Recreational facilities were built not only to create employment, but also to cultivate desirable recreation services for the masses (Kraus, 1998). In addition, the amusement parks appealed to the public with the emphases on their beaches, picnic areas, lawns, and ballrooms. People could enjoy recreation in amusement parks with such facilities, paying only the admission fee. However, drippers who could not afford a dime to use a bathhouse wore clothes over their bathing suits and went back 
home with the dripping water from beaches during the Depression Years (Nasaw, 1993). With the increased unemployment, people had more time than ever to visit these amusement parks which brought increased demand of leisure wear.

Since the 1920s, swimming became popular with the widespread advice that emphasized the importance of physical exercise and getting air and sunlight to the skin. According to Cunningham (1986), swimming was one of Americans' major leisure activities by the 1930s. The increase of unemployment, the popularity of sun-tanning, and the increased number of public beaches and pools built as New Deal projects, all brought more public attention to bathing and swimming.

On the other hand, the popularity of shorts and halters owed not only to the increased unemployment and public parks but also to the popularity of American movies during the 1930s. More than a three forth of Americans went to the movies at least once a week in 1930. Around a half of Americans still went to the movies in 1932 despite the economic depression. Mix-and-match possible casual outfits worn for leisure activities were often featured in Hollywood movies. Halters and shorts along with pajamas were the leisure wear popularized through the movies during the 1930s. Examples of leisure wear could be found in movies such as $42^{\text {nd }}$ street and The gay divorcee (Warner, 2005).

\section{Body Exposure in Leisure Wear}

\section{Popular Bathing Suit Styles}

The most popular styles of bathing suit in the 1930s were the fitted maillot which could be worn with or without over skirts, and a dressmaker style bathing suit with a fitted bodice worn with a short skirt. We can observe the former style of bathing suits in $<$ Fig. 1 $>$. In addition, two-piece bathing suits which exposed the wearers' midriffs as the one in $<$ Fig. 2> were also introduced. Rubber yarns were often used to make close-fitting bathing suits. Lastex, which had a rubber core covered with two other yarns of natural fiber, was introduced to the market in
1931. Bathing suits made of Lastex had two-way stretch (Cunningham, 1986).

Cunningham (1986) found that many women preferred dressmaker styles of bathing suits for several reasons. Dressmaker bathing suits were often designed with a full skirt as described previously. This made the bathing suits look more modest. Another factor that contributed to attaining a more modest look with

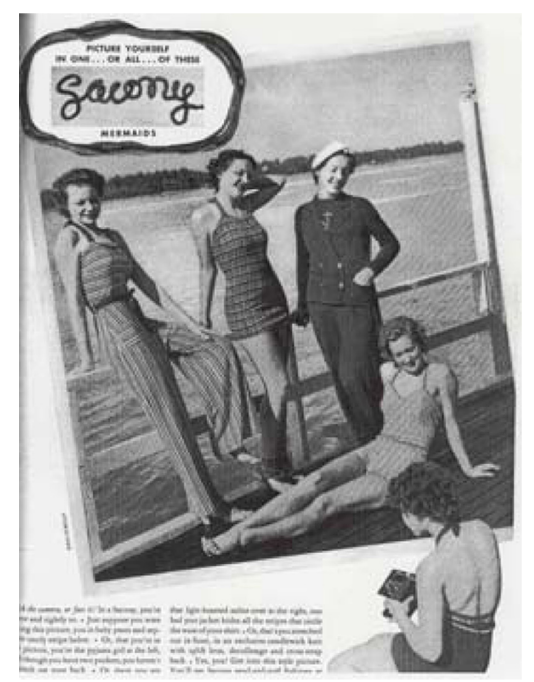

Fig. 1. Bathing suits, pajamas, and a trouser suit. From Sacony advertisement. (1935, June 1). Vogue, 85, p. 115.

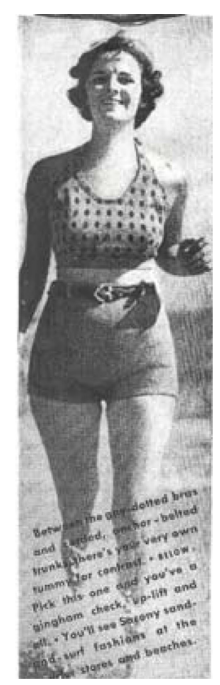

Fig. 2. A two-piece bathing suit.

From Sacony advertisement. (1935, June 15). Vogue, 85, p. 7. 
the dressmaker bathing suits was that they were often made of non-elastic woven materials rather than elastic materials such as Lastex. This made these bathing suits less snug to the body. They were also preferred for the fabrics with fancy and complex patterns. Even though many women preferred modest styles of bathing suits, the public criticized women in bathing suits for revealing too much of their bodies. Many bathing suits were backless, as the one in $<$ Fig. $1>$, in order to display a neat sun-tanned back in evening gowns which exposed much of wearers' backs $<$ Fig. $3>$. Armholes were also getting wider. In addition, bathing suits exposed a larger portion of women's legs compared with the previous period, even though women still covered the upper part of the thighs, as we can observe in $<$ Fig. $1>-<$ Fig. $2>$.

\section{Popularity of Shorts and Halters in the 1930s}

Women in shorts started to appear since the 1920s. According to Wass and Anderson (1990), women's gym outfits usually consisted of knickerbockers and blouses in the 1920s. However, knickerbockers grew

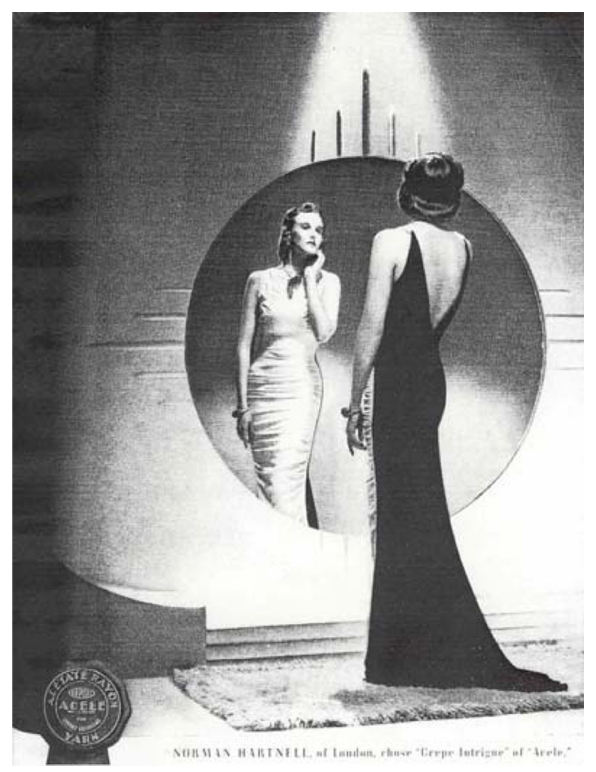

Fig. 3. An evening gown.

From DuPont Acele advertisement. (1938, February 15). Vogue, 91, p. 15. shorter and sometimes women wore shorts instead of knickerbockers. Some women were photographed in shorts, while they were running in the 1920s. In the 1928 Amsterdam Olympics, most women contestants, including American women in field and track, wore shorts with tailored shirts.

Women also wore shorts in playing sports such as tennis and skating in the early 1930s ("Warring against shorts", 1936). The popularity of shorts for women seems to have grown in the mid-1930s. In April 1935, The New York Times reported that shorts sales increased so much that "one manufacturer was compelled to purchase another mill to take care of the orders"("Buys mill", 1935, p. 9). A society woman in $<$ Fig. $4>$ is shown wearing shorts in Palm Beach, Florida.

In addition, halters were popular among women, especially on beaches and in mountains on the East Coast around the 1930s. A woman on $<$ Fig. $1>$ wears one of the halters with a pair of pajamas. Halters were the straps which supported the front part of the garment. Halters were extended around the neck to expose shoulders and back of the wearer. The term halters is used to mean halter-necked garments. Halters became popular first in the 1930s and 1940s, and again in the 1970s (Calasibetta \& Tortora, 2003).

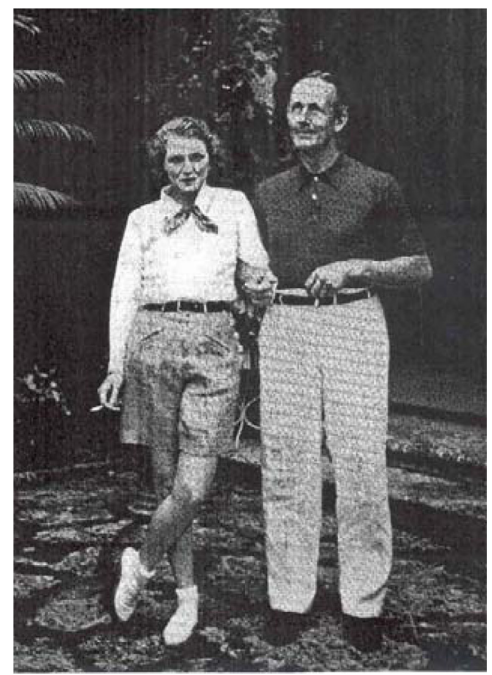

Fig. 4. Shorts

From Mr. and Mrs. Harrison Williams. (1935, June 15). Vogue, 85, p. 63. 


\section{Social Reactions to the Body Exposure in Leisure Wear}

\section{Bathing Suits}

The public tried to impose restrictions on certain styles of bathing suits during the 1930s. One of the styles to be restricted was the "extra-trim bathing costume" which had wide armholes and a bare back, and came down to cover only the upper part of thighs ("Dress for the surf", 1930, p. 2). These abbreviated bathing suits were banned on many beaches, not to mention on the boardwalk and on public streets, throughout the nation in the early 1930s ("Dress for the surf", 1930).

The American Association of Pools and Beaches decided to demand that the bathing suit manufacturers produce less body-exposing bathing suit designs for 1933. The association complained about women wearing overly abbreviated bathing suits, and one of the members explained that the abbreviated bathing suits became popular following the Olympic contestants' appearing in brief bathing suits ("Bathing pool men", 1932).

In 1932, white bathing suits were also banned on the beach in Ocean Grove, New Jersey, which was a very conservative Methodist community of the time. The New York Times reported that the beach manager gave no explanation about the reason for banning white bathing suits ("Beach bans", 1932). It can be inferred that the white bathing suits would become transparent when they turned wet, which would look quite immodest.

On the other hand, there were also indications of burgeoning change in social expectations for bathing suits in some parts of the United States in the early 1930s. In 1932, Mayor Harry Bacharach of Atlantic City, New Jersey, reviewed the styles of bathing suits for the summer, and even approved the ones with "short trunks and a scanty bandeau" ("Bathing style approved", 1932, p. 21). He and other reviewers said that the important thing was not the style of bathing suit one wears, but how one behaves in a bathing suit. However, laces or nets were banned in the bathing suits, along with the design that consisted of a trunk and shoulder straps ("Bathing style approved", 1932).

Recognizing the changing style of bathing suits, a policeman in North Haledon, New Jersey, proposed to the Common Council that the law for the bathing suit style regulation should be changed. According to this town law, people should wear two-piece bathing suits with long sleeves and knee-length bloomers, which were a style from the late $19^{\text {th }}$ to the early $20^{\text {th }}$ century ("Wants new bathing law", 1933).

There appears to have been a gradual change in social expectations of bathing suits, as more women adopted abbreviated bathing suits as the decade went on. Such issues as bathing suits without stockings or exposing bare calves by wearing short socks were out of fashion by the 1930s. It became a tacit agreement that women could go barefoot in bathing suits on the beach, as seen on the women in $<$ Fig. $1>-$ $<$ Fig. $2>$.

Many women defied the restrictions that were imposed on certain styles of bathing suits. By 1939, restrictions on bathing suit styles almost disappeared in primary sources. One writer in The New York Times Magazine declared in 1939 that "it had become pretty generally agreed that sin and swimming are rather incompatible" (Cobb, 1939, p. 15). Referring to Sproles's fashion adoption theory from an aesthetic perspective, people became familiar with the styles of bathing suits which displayed more of women's bodies, as they were repeatedly exposed to the styles (Sproles, 1981).

However, bathing suits continued to be banned in public places outside of many beaches, especially on the East Coast, throughout the 1930s, as they were in the 1920s. Most of the time, the restrictions were not confined to women but also applied to men. Rockaway, in New Jersey, banned men and women from wearing bathing suits on the streets ("Rockaway yields", 1935; "323 rescues at Rockaways", 1935). Bathers were allowed to wear bathing suits only on beaches and at pools in the Palisades Interstate Park in New York in 1936 ("Hikers in shorts safe", 1936). In Long Beach, Long Island, bathing suits were also banned on the boardwalk in 1938 ("Ban is put on suspenders", 1938). By 1938, different beaches had 
different regulations on whether people could wear bathing suits on the boardwalk or on the streets. For example, bathing suits were banned on the boardwalk in Rockaway and Coney Island, while people were allowed to wear bathing suits on the streets in Jacob Riis Park and Orchard Beach in Bronx. The explanation was that Rockaway and Coney Island beach were near residential and business areas ("Rules on raiment", 1938). The imposition of laws restricting bathing suits in these public places suggested that people did wear or attempted to wear bathing suits outside the beach.

In sum, women's bathing suits were restricted in styles for the body exposure. However, many women continued to wear more body exposing styles of bathing suits, many defying the restrictive laws. By the end of the 1930s, such laws almost disappeared, and this represented the change of social expectations for body exposure in women's bathing suits. In addition, the reports of laws which forbade wearing bathing suits in public places outside of beaches and pools on the East Coast meant that some people dared to expose more of their bodies away from the beach. This trend could also be observed in controversies related to some women's shorts and halters during the period.

\section{Shorts and Halters}

In the mid-1930s, many reports on regulating shorts and halters in Yonkers, a town in New York, appeared in The New York Times. Yonkers' residents protested against women hikers in shorts passing by their neighborhoods, especially on Sundays, as they were going to Tibbetts Brook Park for hiking. In 1935, five women attired in shorts and halters were caught, under the city law banning "appearance on a city street of any person in scanty attire" and were brought to the local court ("Girl hikers haled", 1935, p. 19). The judge told the women that "all we desire you to do is just dress the way the women in Yonkers dress when upon our public streets."("Hikers in shorts", 1935, p. 6). A reader then protested to The New York Times that wearing street garments in hiking was "merely unhygienic," and "just too charmingly
Victorian" ("Yonkers standards", 1935, p. 16). However, the ordinance was revised twice to specify that "a bathing suit, shorts, halter or any costume or clothing which indecently exposes or reveals any part of the wearer's person" were forbidden on the Yonkers streets ("Anti-shorts ban upheld", 1937; "New antishorts law", 1937, p. 7; "Yonkers aldermen vote ban", 1935). No violators were found in Yonkers, under the revised ordinance, but confrontation over abbreviated attire continued to be reported until 1938 ("Scanty costumes absent", 1937; "Yonkers set for hikers", 1938).

Following the case of Yonkers, shorts and halters were banned on the streets of Suffern, New York in 1935 ("Suffern bans shorts", 1935). Shorts were also banned in Camp Smith in New York where soldiers were in summer training. Colonel Walter Delamater, in charge of the regiment, thought that women in such attire would "affect his young men," and commented that "it looks bold on the part of young women who dress that way" ("Girls in shorts", 1935, p. 15). The colonel's comments on women's shorts in the camp connoted women's open allurement of young soldiers with exposed bodies.

In 1936, shorts and halters were banned in shopping areas in Westport, Connecticut. However, there was no State statute that would validate police actions on the violators ("Petition against shorts", 1936). In Convington, Kentucky, the police declared that they would arrest females over 10 years of age wearing shorts on the streets ("Warring against shorts", 1936).

In Babylon, New York, a young woman was forced out of a church by a priest, for wearing a halter and slacks. She went to the church in beach attire for confession, not knowing the confession hours. After the priest ordered her out of the church, she came back with her jacket on, but the priest still tried to "pull her from the pew" ("Girl in church row", 1936; "Priest eject girl", 1936, p. 21). Not only the body exposure but also the slacks were the problem to the priest. Proper attire for the church required skirts for women.

The ban against shorts on the streets continued in the late 1930s. In 1938, an ordinance banning "gar- 
ments [that] unnecessarily expose or reveal any part of the wearer's person" in shopping areas was passed in Great Neck, Long Island ("Breakers ahead", 1938, p. 20). The vague statement of the ordinance would cause controversy over whether wearing shorts in the hot weather would be an unnecessary exposure of bodies. It was mentioned in The New York Times that it "involves a basic issue of human freedom and some subsidiary problems in esthetics" ("Breakers ahead", 1938, p. 20). This comment connoted that an individual's body exposure could be viewed as a personal freedom of choice in clothes rather than as an offensive behavior to disrupt the established social conventions which should be regulated and criticized.

While some authorities were imposing restrictions on shorts and, there rose an argument that the restrictions were the question of esthetics. It was insisted that the reason for residents' protest against shorts in Yonkers was esthetics rather than morality, since many residents were bothered by the hikers - many of them were fat-displaying "too fleshy bodies" ("Shorts and the law", 1935; "Contours are modern", 1936; "Yonkers war on shorts", 1936, p. 3). It must have seemed too old fashioned to give morality as a reason for banning shorts and halters on the streets which hikers had to across on their way to the park for hiking. Emphasis on esthetics rather than morality in interpreting the protest in Yonkers seemed to reflect the recognition of change in social expectation on body exposure in women's fashion.

The evidence and the recognition of change in social expectation were also observed in other East Coast areas. In 1935, Rockaway Chamber of Commerce attempted to "tighten a city ordinance against wearing bathing suits on the streets, to include the wearing of shorts" ("323 rescues at Rockaways", 1935, p. 3). The Rockaway chamber asked for support from Coney Island. However, Coney Island organizations had a flexible view about wearing shorts. The Rockaway chamber also decided to allow shorts on the beach front, saying that "of late there has been an entire change of attitude on what constitutes modesty, and if we try to be somewhat dignified we lose our standing as moderns" ("Rockaway yields," 1935, p. 17). According to Marchand (1986), modernity meant "urbanity, youthfulness, mobility, optimism, and tolerance for diversity and speed of change" in the 1920s and the 1930s. Rockaway's legislators recognized and admitted that there were some changes in social expectations about women's body exposure, and they had to accept and be tolerant of the changes in order to keep abreast of modernity.

In addition, in 1936, in the Palisades Interstate Park, in New York, the park manager allowed shorts in the park, saying that "I see no use in interfering with hiking costumes, because the hikers are going to wear what they please in any event" ("Hikers in shorts safe", 1936, p. 6). Another liberal view on shorts could be found in Danbury, Connecticut. A florist, who was on the forefront of the protest against women's shorts, attempted to present an ordinance that was similar to the one in Yonkers. However, no action was taken by the Mayor ("Plans Danbury war on shorts", 1936). In sum, there were people who insisted on their freedom in clothing selection, and these people contributed to bring the change in social expectations regarding women's body exposure in public places during the 1930s.

Overall, American women attempted to expose more of their bodies in bathing suits, shorts and halters during the 1930s. Moreover, some women wore these leisure wear outside the parks and resorts. The public criticized and tried to ban the abbreviated styles and these leisure wear worn on the streets. However, the gradual disappearance of reports on these issues represents the change of social expectation in women's body exposure.

\section{Conclusions}

Many women exposed more of their bodies in the 1930 s, despite the popularity of longer skirts in mainstream fashion. Many women's bathing suits grew more body revealing, and The New York Times reports showed that more women wore shorts and halters as leisure wear. The popularity of movies which featured body exposure in leisure wear also had an influence on the fashion trends of the time (Warner, 2005).

However, the trend toward more flexibility in 
social customs with the change in the concept of modesty in women's fashion could be observed from the change of social regulations which permitted more abbreviated leisure wear styles and the gradual disappearance of social criticism on the body exposure of these styles. Blumer (1969)'s concept of "developing tastes" served women to adopt the styles which challenged the traditional standard of modesty in body exposure.

In addition, the existence of the ordinances against abbreviated leisure wear styles reflected the existence of force which acted to change the social expectations in relation to body exposure in women's fashion. In line with Davis (1992) and Nagasawa et al. (1995), the controversies about women's body exposure demonstrated the existence of ambivalence about the proper amount of body exposure to be allowed within the society, and the social negotiation process of establishing a new dress code. The gradual disappearance of discussions and reports on restricting bathing suits, shorts and halters by the late 1930s represented the change of social expectations about body exposure as the society became accustomed to more exposure of bodies in women's fashion.

On the other hand, the ordinances banning bathing suits, shorts, and halters in the public places outside the beach implied that more women grew daring in exposing more of their bodies in public places, especially on the East Coast. These phenomena reflected another trend toward less occasion-specific clothing behavior during the 1930s. Payne et al. (1992) suggested the influence of sportswear on less occasionspecific clothing with the increase of leisure time and mobility in the first half of the twentieth century. Bathing suits, shorts and halters which were originally worn for sports activities started to appear on the streets during the 1930s. This was a partial step toward the change in the concept of sportswear from garments worn for sports activities to mix-and-match possible separate pieces of garments (Calasibetta \& Tortora, 2003). In another words, the abbreviated styles of leisure wear worn on the streets during the 1930s contributed to creating today's street styles mostly composed of sportswear that are less occasion-specific, casual, and informal.
Overall, the significance of the body exposure in women's leisure wear during the 1930s can be summarized as follow: The change in social expectation about women's body exposure and the contribution to the popularization of abbreviated, less occasion specific garments - leisure wear, i.e. sportswear. The research on the change of social reactions to women's body exposure in leisure wear including bathing suits, shorts, and halters, provides a better picture of the change in social expectations about women's body exposure and the concept of modesty. Moreover, the analyses of reports on abbreviated leisure wear worn on the streets also offer a better understanding about the process of how sportswear worn for leisure activities gained nowadays broader concept. However, the fact that most of the reports were about American East Coast serves as a limitation of this research. Despite the limitation, the change in meanings of women's body exposure could be better understood as a process of change in dress code through this research. The findings of this research will contribute to enhance the knowledge about the history of women's fashion.

\section{References}

Anti-shorts ban upheld. (1937, January 6). The New York Times, p. 18.

Ban is put on suspenders on Long Beach boardwalk. (1938, June 26). The New York Times, p. 25.

Bathing pool men demand ban on scant suits: Petition makers for reforms in 1933 Models. (1932, December 3). The New York Times, p. 9.

Bathing styles approved. (1932, May 24). The New York Times, p. 21.

Beach bans white bathing suits. (1932, July 1). The New York Times, p. 11.

Blumer, H. (1969). Fashion: From class differentiation to collective selection. The Sociological Quarterly, 10(3), 275291.

Bolitho, W. (1930, Ferbruary). The new skirt length. Harper's Magazine, 957, pp. 292-296.

Breakers ahead. (1938, April 29). The New York Times, p. 20.

Burgess, J. P. (1932, April). Back to Victoria. Outlook, 160(7), 223-225.

Buys mill for new shorts. (1935, April 14). The New York Times, p. 9.

Calasibetta, C. M., \& Tortora, P. G. (2003). Fairchild dictionary of fashion $\left(3^{\text {rd }}\right.$ ed.). New York: Fairchild. 
Cobb, J. (1939, July 23). For freedom by the seas. The New York Times, sec. 7, pp. 10-11, 15.

Commager, H. S. (1950). The American mind: An interpretation of American thought and character since the 1880's. New Haven: Yale University Press.

Contours are modern. (1936, June 2). The New York Times, p. 26.

Cunningham, P. (1986). Swimwear in the thirties: The B.V.D. Company in a decade of innovation. Dress, 12, 11-27.

Davis, F. (1992). Fashion, culture, and identity. Chicago: The University of Chicago Press.

Dress for the surf. (1930, July 27). The New York Times, sec. 9, p. 2.

DuPont Acele advertisement. (1938, February 15). Vogue, 91, p. 15.

Flügel, J. C. (1931, December). The psychology of clothes. Golden Book Magazine, 14(84), 435-438.

Girl hikers haled for "scanty" attire. (1935, June 17). The New York Times, p. 19.

Girl in church row defends her attire. (1936, August 18). The New York Times, p. 21.

Girls in shorts are barred at Camp Smith: Delamater fears effect on his solders. (1935, July 5). The New York Times, p. 15.

Hikers in shorts freed in Yonkers. (1935, June 18). The New York Times, p. 6.

Hikers in shorts safe in the Palisades Park. (1936, July 28). The New York Times, p. 6.

Kraus, R. (1998). Recreation and leisure in modern society ( $5^{\text {th }}$ ed.). Boston: Jones and Bartlett Publishers.

Marchand, R. (1986). Advertising the American dream: Making way for modernity, 1920-1940. Berkeley: University of California Press.

Mr. and Mrs. Harrison Williams. (1935, June 15). Vogue, 85 , p. 63.

Nagasawa, R. H., Kaiser, S. B., \& Hutton, S. S. (1995). Construction of an SI theory of fashion: Part 2. from discovery to formalization. Clothing and Textiles Research Journal, 13(4), 234-244.

Nasaw, D. (1993). Going out: The rise and fall of public amusements. New York: Basic Books.

New anti-shorts law is passed in Yonkers. (1937, July 21). The New York Times, p. 7.

Payne, B., Winakor, G., \& Farrell-Beck, J. (1992). The history of costume: From ancient Mesopotamia through the twentieth century. New York: Harper Collins Publishers Inc.

Petition against shorts. (1936, July 14). The New York Times, p. 21.

Picken, M. B. (1999). A dictionary of costume and fashion: Historic and modern. Mineola, NY: Dover.

Plans Danbury war on shorts. (1936, August 12). The New York Times, p. 13.

Priest eject girl in slacks from church: Warns "half-naked morons" to stay away. (1936, August 17). The New York Times, p. 21.

Rockaway yields to the shorts fad. (1935, July 29). The New York Times, p. 17.

Rules on raiment perplex bathers. (1938, July 3). The New York Times, p. 14.

Sacony advertisement. (1935, June 1). Vogue, 85, p. 115.

Sacony advertisement. (1935, June 15). Vogue, 85, p. 7.

Scanty costumes absent. (1937, August 30). The New York Times, p. 23.

Shorts and the law. (1935, June 22). The New York Times, p. 14.

Sproles, G. (1981). The role of aesthetics in fashion-oriented consumer behavior. In G. B. Sproles (Ed.), The perspectives of fashion (pp. 183-192). Minneapolis: Burgess Publishing Company.

Stolberg, B.(1926, December). The man behind the times. In E. H. Ford \& E. Emery (Eds.), Highlights in the history of the American press. (pp. 362-370). Minneapolis: University of Minnesota Press.

Suffern bans shorts as "immodest attire". (1935, June 25). The New York Times, p. 15.

Yonkers aldermen vote ban on shorts. (1935, July 3). The New York Times, p. 19.

Yonkers set for hikers. (1938, May 15). The New York Times, p. 31.

Yonkers standards. (1935, June 24). The New York Times, p. 16.

Yonkers war on shorts laid to "vulgarity" of fat. (1936, June 1). The New York Times, p. 3.

Wants new bathing law. (1933, August 15). The New York Times, p. 3.

Warner, P. C. (2005). The Americanization of fashion: Sportswear, the movies and the 1930s. In L. Welters \& P. A. Cunningham (Eds.), Twentieth-century American fashion (pp. 79-98). Oxford, UK: Berg.

Warring against shorts: Towns are undecided whether the issue is one of morals or esthetics. (1936, July 26). The New York Times, sec. 9, p. 9.

Wass, A. B., \& Anderson, C. (1990). What did women wear to run? Dress, $17,169-184$.

323 rescues at Rockaways. (1935, July 15). The New York Times, p. 3. 